\title{
Missionary Work, Secularization, and Donor Dependency: Rockefeller-Near East Colleges Cooperation after World War I (1920-1939)
}

\author{
Philippe Bourmaud
}

Relations with foreign donors often put humanitarian NGOs and academic institutions in a catch-22. On the one hand, competition for funding allows major donors to impose political agendas upon them. On the other hand, with the exception of boogeymen such as George Soros, aid-receiving organizations, rather than donors, are generally blamed in local political discourse for the enforcement of external agendas. In contemporary Egypt and Israel, this suspicion has served as a pretext to take on foreign-funded NGo s. ${ }^{1}$ Agenda dependency induces to favour professionalism and capacity of action over political and axiological commitment, ${ }^{2}$ and is therefore seen as a seemingly non-political vehicle for hidden agendas.

Faith-based private voluntary organizations have a history from that perspective. In the late Ottoman Empire and Republican Turkey, missionary organizations have been denounced as the instruments of imperialistic states, the vehicles of cultural domination, and the perpetrators of a spiritual blackmail to attract missionized population under external influence. What is true of the Middle East would also be relevant in other former colonial or non-Western countries such as India and China. Yet in the last few decades, faith-based NG o s have banked on their religious nature to bolster their credibility: religious values have been publicized as a guarantee of reliability and of autonomy vis-à-vis major donors. ${ }^{3}$

1 "Egypt: New Law Will Crush Civil Society," Human Rights Watch, June 2, 2017, accessed April 27, 2018, https://www.hrw.org/news/2017/o6/o2/egypt-new-law-will-crush-civil-socie ty; Peter Beaumont, "Israel Passes Law to Force NGO s to Reveal Foreign Funding," The Guardian, July 12, 2016, accessed on April 27, 2018, https://www.theguardian.com/world/2016/jul/ 12/israel-passes-law-to-force-ngos-to-reveal-foreign-funding.

2 For a Palestinian example: Caroline Abu-Sada, oNG Palestiniennes et construction étatique: L'expérience de Palestinian Agricultural Relief Committees (PARC) dans les Territoires occupés palestiniens 1983-2005 (Beirut: Presses de l' IF PO, 2013).

3 Marie-Juul Petersen, For Humanity or for the Umma? Aid and Islam in Transnational Muslim NGO S (Oxford: Oxford University Press, 2016). 
Does the religious nature of the organizations make them more susceptible to dependency on external donors, or more autonomous, than secular ones? And why do they seem to show varying receptibility to the influence of external donors? Part of the answer lies in context and the ways in which donor dependency works: the patterns of donor dependency are polymorphous and multidirectional, depending on the length of the relation, and on the donors' capacity of control on the ground. ${ }^{4}$ Differences are usually explained by varying effectiveness in following up on the procedures of project evaluation, ${ }^{5}$ rather than on account of intrinsic features of the organizations. But faithbased private voluntary organizations working abroad are held to a mission statement, in the strong, literal sense. Their receptivity to external influence lies less in their stated goal than in what they do, which is not limited to proselytizing. Over the 19th and early 2oth centuries, the functions assumed by missionaries expanded into assistance to women and families, education, medicine, higher education, and relief work in the midst of humanitarian crises. The trend imposed a parallel increase in financial resources.

How to analyze the way the religious factor plays without assumptions of instrumentality at the service of external agents and institutions, or of specificity of religious callings? One way to compare secular and missionary receptivity to the influence of donors is to consider missionary institutions that change their general perspective and become secularized.

The cooperation between American Protestant missionary colleges in the Middle East and the Rockefeller Foundation ( $\mathrm{RF}$ ) is a test case here. In the Middle East, the post-World War I period saw the Near East Colleges Association (NECA), a group of American Protestant academic institutions, apply for RF funds. It included institutions founded by the (Presbyterian) American Board of Commissioners for Foreign Missions (ABCFM), such as Robert College and the American College for Girls (ACG, also known as Constantinople Woman's College) in Istanbul and the Syrian Protestant College (SPC) in Beirut. ${ }^{6} \mathrm{RF}$ money implied the adoption of secular methods of sanitary and social service. The institutions forming the Near East College Association were already moving towards secular methods and outwardly secular goals, and it is

4 Jeffrey A. Lefebvre, "Donor Dependency and American Arms Transfers to the Horn of Africa: the F-5 Legacy," The Journal of Modern African Studies 25, no. 3 (September 1987): 465-488.

5 Charles H. Kennedy, Ijaz Hussein, and S. Akbar Zaidi, "Reconsidering the Relationship between the State, Donors, and NGo s in Bangladesh [with Comments]," The Pakistan Development Review 38, no. 4 (Winter 1999): 489-510.

6 This research benefited from a travel grant of the Rockefeller Foundation to do research at the Rockefeller Archives Center (Tarrytown, NY). 
worth asking to what extent $\mathrm{RF}$ influence accelerated the evolution. Of significance here is the fact that the RF-NECA cooperation developed as the foundation and the colleges were all involved in humanitarian relief work delivered under the umbrella of the American Committee for Armenian and Syrian Relief established in 1915, later to be renamed the Near East Relief (NER) after World War I, and finally the Near East Foundation (NEF) in 1930. What role did the colleges' own needs, the strategic plans of the Rockefeller Foundation and the circumstances of their common involvement in humanitarian action play respectively in shaping RF-NECA cooperation and the values of the colleges?

Cooperation between an American philanthropy such as the Rockefeller Foundation and American missionaries raises a more general question of strategy. Specialists of missionary history have criticized the idea that Western missions were the instruments of national strategies and more generally warned against strategic readings of missionary work, which often produced "unexpected" effects. ${ }^{7}$ Yet historians of international relations have recently put forward analyses of the operations of American private voluntary organizations abroad based on an orchestrated effort inspired by nationalism. David Ekbladh describes a convergence of public and private actors in the pursuit of global modernization starting in the 1910s, which "was not always humanitarian, but strategic"8 and paved the way for government-led cooperation programs.

Understanding the convergence of views materialized by the cooperation between the Rockefeller Foundation and the Near East colleges requires more than invoking a shared nationalism with strong Protestant undertones, but less than positing missionaries as tools of modernization designed to serve foreign policy, in a predefined global modernization plan. The Rockefeller Foundation and the colleges had their own, largely financial concerns, and it is fair to ask if the convergence of their views in the 1920 s resulted from shared secular and nationalistic views on cooperation, wholesale strategic planning, or more opportunistic exertions of influence enabled by donor dependency.

A related question is that of instrumentality. Did the Rockefeller Foundation manage to instrumentalize the Near East colleges in the pursuit of a global strategy —and if so, whose strategy? Historiography has dwelled on the massive RF projects conducted in China in the first half of the 2oth century, to

7 Heather J. Sharkey, "Introduction: The Unexpected Consequences of Christian Missionary Encounters," in Cultural Conversions: Unexpected Consequences of Christian Missionary Encounters in the Middle East, Africa, and South Asia, ed. Heather J. Sharkey (Syracuse, NY: Syracuse University Press, 2013), 1-26.

8 David Ekbladh, The Great American Mission: Modernization and the Construction of an American World Order (Princeton: Princeton University Press, 2010), 2. 
support the notion of global modernization developing under strategic planning. But looking at the Middle East may help relativize the notion, even though NECA officials paid close attention to the Chinese case. Cooperation, growing out of a situation of humanitarian emergency, left the Near East colleges in an inferior position. Yet it did not entail a takeover by the foundation. This owed to the latter's goals of local capacity-building rather than building an academic empire, but also to missionary techniques of crowdfunding. Donor pressure did not shape the colleges like clay, but tried to set goals and standards without entangling itself in a long-term pattern of patron-client relationship. The influence of the foundation did, however, contribute to the academic differentiation between the colleges and the rationalization of their financial organization, leading to the incorporation of the Near East Colleges Association in 1927.

\section{Missionary Colleges into Humanitarian Institutions}

\subsection{Contested Missionary Methods}

RF-NECA cooperation depended on an agreement on common goals, which was not a forgone conclusion. Protestant foreign missions, starting from scratch in the Middle East, Africa, South Asia, and China in the early 19th century, generally took conversion to be the first and utmost humanitarian goal of all their diverse endeavours: religious propaganda, but also auxiliary work such as medicine, visits to women, teaching, engineering, or professional training. ${ }^{9}$ Auxiliary work often had a tag on it, namely that it should explicitly serve the primary goal of proselytizing, possibly at the expense of its own ends.

Missionary methods matched this aim, at the expense of other this-worldly goals. Missionaries aimed at making contacts far and wide on the missionary field and affording as much religious discussion time as possible. Yet this often clashed with the deontology of auxiliary work, such as medical mission, "women's work", relief, or professional training. ${ }^{10}$ The missionary dimension of auxiliary work was often under scrutiny. This may be overlooked because, on account of the difficulty to broach religious discussion with non-Christians

9 Terril E. Lautz, "The SVM and Transformation of the Protestant Mission to China," in China's Christian Colleges: Cross-Cultural Connections, 1900-1950, eds. Daniel Bays and Ellen Widmer (Stanford: Stanford University Press, 2009), 12.

10 John S. Baick, "Cracks in the Foundation: Frederick T. Gates, the Rockefeller Foundation, and the China Medical Board," The Journal of the Gilded Age and Progressive Era 3, no. 1 (2004): $72-73$. 
in certain fields, China and the Middle East especially, medicine and education became prominent dimensions of Christian missions. Yet from a missiological point of view, neither of them was a consensual method. For most of the 19th century and even beyond, there were differences on how to use them and what for, and on whether they should be regarded as a form of mission in themselves. ${ }^{11}$

These debates and repeated caveats urging missionaries to maintain the priority of the mission's religious goals shaped the methods and atmosphere of the missions. Medical missions were warned against developing central hospitals. It was feared medical service should, to quote a medical missionary journal of the Anglican Church Missionary Society (CMs), "demand too exclusively the energies and attention of those who are in charge. The Medical Missionaries, if they are to do effective pioneer work, must not be too much tied to the centre". ${ }^{12}$ Much importance was given to bedside talk, as well as to itinerations away from the urban centres as a way to attract patients liable to be hospitalized, in order to find occasion for discussion on religion. ${ }^{13}$ Missions tended to be labour-intensive and despite the numerical preponderance of indigenous missionaries, ${ }^{14}$ this pushed payroll expenditure up.

High labour costs and the dissemination of missionaries made it necessary for missionary societies, which were not self-supporting, to prioritize rigorously their expenditure. What would in time come to be regarded as the humanitarian dimension of missionary work was contested from within as a financial distraction from strictly religious endeavours. Medical mission was looked down on as "hardly more than bribes to draw people to hear the Gospel, mere secular adjuncts to missionary work". ${ }^{15}$ True enough, medical and educational work was accepted, if only because competition with Catholic missions created an incentive to occupy the field. ${ }^{16}$ Still, missionary supervising bodies tended

11 Ryan Dunch, "Science, Religion, and the Classics in Christian Higher Education to 1920," in China's Christian Colleges: Cross-Cultural Connections, 1900-1950, eds. Daniel Bays and Ellen Widmer (Stanford: Stanford University Press, 2009), 59-63; Samir Boulos, European Evangelicals in Egypt (1900-1956): Cultural Entanglements and Missionary Spaces, Studies in Christian Mission 48 (Leiden: Brill, 2016), 82-94.

12 A. Lankester, "Some Observations on General Mission Policy," Mercy and Truth vol. 1, no. 10 (October 1897): 223 .

13 Lankester, "Some observations," 220; Albert Cook, "Medical Itineration," Mercy and Truth vol. 5, no. 66 (June 1902): 174-179.

14 Sharkey, "Introduction," 11.

15 H. Lankester, "Medical Missions in Theory," Mercy and Truth vol. 3, no. 38 (February 19oo): 38.

16 See, among others: Julia Hauser, German Religious Women in Late Ottoman Beirut: Competing Missions, Studies in Christian Missions 45 (Leiden: Brill, 2015); Nazan Maksudyan, 
to object. Higher education was an even more fraught issue: it was intended to serve missions by providing trained indigenous staff, but it appealed to students far beyond potential missionaries, among Muslims in particular. Was it worth the cost?

\subsection{An Expanding Branch of Auxiliary Work: Missionary Colleges and Social Service and Relief as New Goals}

Missionary colleges multiplied before World War I. In the Ottoman Empire, they were uniformly Presbyterian. The ABCFM had started founding missionary colleges in the Ottoman Empire in the 1860s, initially with a view to training future missionaries. In Istanbul, Robert College was founded in $1863,{ }^{17}$ followed by the American College for Girls, established in 1871 and reorganized in $1890 .{ }^{18}$

Yet much like medical missions and schools, Protestant missionary colleges were contested as a diversion from narrowly missionary, i.e. propagandistic functions. It had been argued, in their early years, that to train indigenous missionaries, they should welcome converts or children of converts only. ${ }^{19}$

By the 189os, stated goals were changing. Major Protestant missionary organizations had started putting a stress on efficiency in auxiliary work. Investments in medical missions grew accordingly. The ends of the various forms of auxiliary work came, grudgingly, to be considered in their own rights.

This transformation went against the practice of missionary organizations, that had grown global through bureaucratic control and the assimilation of cost/benefit analysis. What Delphine Gardey has called "a revolution of paper"-keeping and possibly typing records, using charts, posting financial data into a bureaucratic apparatus-intensified long-distance operations. ${ }^{20}$ The Near East colleges could be supervised by a board of New Yorker patrician

Orphans and Destitute Children in the Late Ottoman Empire (Syracuse, NY: Syracuse University Press, 2014); Lorella Ventura, Hegel in the Arab World: Modernity, Colonialism, and Freedom (London: Palgrave MacMillan, 2018).

17 Aslı Gür, "Robert College: Laboratory for Religion, Shrine for Science-Transculturation of Evangelical College Model in Constantinople," in American-Turkish Encounters: Politics and Culture (1830-1989), eds. Nur Bilge Criss, Selçuk Esenbel, Tony Greenwood, and Louis Mazzari (Newcastle upon Tyne: Cambridge Scholars Publishing, 2011), 48-6o.

18 Mary Mills Patrick, A Bosphorus Adventure: Istanbul (Constantinople) Woman's College, 1871-1924 (Stanford: Stanford University Press, 1934).

19 Loren W. Crabtree, "Andrew P. Happer and Presbyterian Missions in China, 1844-1891," Journal of Presbyterian History 62, no. 1 (Spring 1984): 31; Paul W. Harris, "Cultural Imperialism and American Protestant Missionaries: Collaboration and Dependency in MidNineteenth-Century China," Pacific Historical Review 6o, no. 3 (August 1991): 334.

20 Delphine Gardey, Ecrire, Calculer, classer: Comment une révolution de papier a transformé les sociétés contemporaines, 1800-1940 (Paris: La Découverte, 2008). 
trustees after their registration in the state of New York. But on account of the distance, supervision of the missions rested on quantifiable criteria of efficiency. The institutions now aimed at more secular goals: rationalization through centralization, promoting science-based policy making, and training a socially aware leadership. ${ }^{21}$

This was partly due to the trends in the recruitment of missionaries abroad. Starting in the 189os, American missionary organizations, under the influence of progressive nationalism, gave increased importance to social service work.

War circumstances shaped the mutation of missionary colleges into relief organizations. With the 1915-1916 famine, the SPC collaborated with the American Red Cross to transfer food and money to the Syrian population, set up soup kitchens in Beirut and dispensaries. ${ }^{22}$ After the end of the war, the NER brought together missionary organizations, American missionary colleges, and philanthropies headed by the Rockefeller Foundation. ${ }^{23}$ Missions and Protestant colleges played an active role in the NER. ${ }^{24}$ The NER, after 1930 the NEF, would continue working with RF money and in cooperation with the AUB all through the Interwar years before expanding its geographical scope, focusing on rural development.

The second consequence of the war, for the colleges, was a cash crunch. Relief operations were a drain on their budget, entailing sudden jumps in contingency expenditure. Impoverished families were hard put to pay the tuition fees. ${ }^{25}$ The devaluation of the us dollar in 1917 reduced the purchasing power of the colleges' income, as donations were labelled in us currency. ${ }^{26}$ Following World War I, American missionary colleges were pressed to find ready money. RF-missionary cooperation was already well under way in China, but it took the emergency of the post-war years for it to take shape in the Middle East.

\footnotetext{
21 Lautz, "The svM," 4.

22 Watenpaugh, Bread from Stones, 47-54.

23 George E. Vincent, The Rockefeller Foundation: A Review for 1919; Public Health and Medical Education in Many Lands (New York: The Rockefeller Foundation, 1920), 36.

24 Near East Relief, Report to Congress for 1925 (New York: Near East Relief-National Headquarters, 1926), 11-12.

25 Dong Wang, Managing God's Higher Learning: U.S.-China Cultural Encounters and Canton Christian College (Lingnan University) 1888-1952 (Lanham, MD: Lexington Books, 2007), 96; Robert College Records (New York: Columbia University Libraries, Rare Book and Manuscript Library), available at Boğaziçi Üniversitesi Archives, Istanbul (hereafter CUL/ RBML, RC), American College for Girls Records (hereafter ACG), Box 20, file 18: President's Report with Statistics 1920-1921, 16-17.

26 Wang, Managing God's Higher Learning, 96.
} 


\section{Near East Colleges Association: Secularization and Institutional Competition}

2.1

A Gradual Trajectory out of Debt

In the Middle East, it was post-war emergency and heavy debts, not a strategic plan, that prompted the Near East colleges to take an interest in the Rockefeller Foundation. The latter had already been involved in the foundation, in 1915, of the American Committee for Armenian and Syrian Relief, the forerunner of the NER. ${ }^{27}$ In 1920, a promise was made by the Rockefeller Foundation to examine the circumstances under which a program of direct help to the Near East Colleges Association could happen. ${ }^{28}$ Yet over the next four years, the adoption of a cooperation plan was postponed due to hesitations from the foundation.

Cooperation between the Rockefeller Foundation and the Near East Colleges Association was instituted in three steps. Big donations were campaigned for in order to face economic hardships when the association launched an emergency plan in 1922, as Beirut and Istanbul were facing masses of incoming refugees. Formal cooperation took the form of a contingency plan to solve debt problems and train professional researchers by 1924. An expansion plan to achieve the transformation of the colleges into research institutions after 1927. I will dwell mostly on the former two plans here.

\subsection{Ecologies of Project Planning}

The Near East colleges were not completely a new matter for the Rockefeller philanthropy, but the post-war conditions led to a vast increase of the aid. John D. Rockefeller had long funded the SPC at the tune of $\$ 5$,000 a year, yet more ambitious contributions were initiated by the fund dedicated to the memory of his wife, the Laura Spelman Rockefeller Memorial Fund (LSRM). When the Near East Colleges Association launched a first donation drive to face the immediate needs of the colleges and the increased expenses due to the relief operations they participated in, the LSRM gave the largest contribution, a third of the grand total of $\$ 1,102,000$ that were collected. ${ }^{29}$

\footnotetext{
27 John Branden Little, "Band of Crusaders: American Humanitarians, the Great War, and the Remaking of the World" (PhD diss. in history, University of California (Berkeley), 2009), 110, note 129 .

28 Rockefeller Archives Center, Tarrytown, NY (hereafter RAC), Rockefeller Foundation Record (hereafter RF), RF Diaries, George E. Vincent, "Interview with Dr. Dorman of the Beirut Medical School 25 February 1924."

29 Cyrus Schayegh, "The Interwar Germination of Development and Modernization Theory and Practice: Politics, Institution Building, and Knowledge Production Between the Rock-
} 
Yet the Rockefeller Foundation remained reluctant to embark on a fullyfledged cooperation plan in the Middle East. The foundation required an assessment according to its own procedures of evaluation through an inspection tour by RF officials. The foundation as a whole postponed any contingency plan for the Near East colleges before an inspector of its own had made an assessment of the possibilities of medical cooperation. ${ }^{30}$ The foundation was undecided about when to start cooperation, which in a shifting regional and educational landscape meant about whether to cooperate at all.

\subsection{Cooperation and Secularization}

Strikingly, the colleges were eager to comply with RF demands in order to get out of financial problems and reexpand. Most effective was the scaling of the provision of aid, which enabled the RF, not only to impose its procedures of examination, but also to establish cooperation on a basis of external consensus on the goals of the RF-NECA project; this, despite the fact that it was actually reluctant to get involved in the Middle East for the time being, and did not have a clear plan for the region or the colleges.

The second step towards a common cooperation project saw the agreement of the Rockefeller Foundation around the medical sciences, in 1924, and a donation drive to complete it in 1925-1926. The head of Medical education at the foundation, Richard M. Pearce, and its director, George E. Vincent, undertook an inspection tour in the Middle East and were convinced by a well-prepared faculty at the American University of Beirut, as the SPC had been renamed in $1920 .{ }^{31}$ The foundation was setting its conditions and ended up imposing its timetable. Did these conditions pertain to the colleges' missionary character?

$\mathrm{RF}$ officials do not refer much to the missionary nature of the proposed cooperation in the Middle East. What they say and what they do, though, reflects a desire to avoid starting projects with openly missionary institutions.

In the Middle East as in China, missionary milieux were divided on the secularization of their work. Humanitarian action within the framework of the China International Famine Relief Commission and the NER and the prospect of cooperation with the Rockefeller Foundation were widening the gap. The division among missionaries in the Middle East overlapped with a division between missionary and more secular colleges, resulting in the limited list of

efeller Foundation and the American University of Beirut," Geschichte und Gesellschaft 41, no. 4 (October-December 2015): 669 .

$30 \quad$ AUB/ASC, A.A.7.6.2, AUBites, 9, "STAU B, A.w.," Box 2: Staub to Nickoley (February 17, 1923); Staub to Nickoley (April 24, 1923).

31 RAC, RF, RF Diaries, Richard M. Pearce (April 6, 1924); (May 22, 1924). 
the Near East colleges. Among the more missionary institutions stood out the American University in Cairo (AUC). ${ }^{32}$ The AUC was also home to some of the more vocal critics of the secularization of the AUB. ${ }^{33}$ The division between the colleges became a matter of money as the prospect of $\mathrm{RF}$ funding loomed.

The competition for funding reflected the preferences of the Rockefeller Foundation for secularized institutions and the notion it nurtured that these alone had a promising future in the Middle East. After the perimeter of the cooperation between the foundation and the Near East Colleges Association had been determined, a NER conference in Istanbul in 1927 would stress the uncertainties that the future held for the smaller, unfunded colleges. They were left with the choice between to continue teaching without aid, or to adapt to the $\mathrm{R} F$ agenda of rural development. ${ }^{34}$ In any case, the "three large institutions" which came had initially formed the Near East Colleges Association concentrated the financial resources-both on account of their secular outlook and of the guarantee of viability provided by their size.

The final list of the Near East colleges was not the result of a strategic plan, but a negotiated result, a group of institutions that not only could live with the secularized perspective of the Rockefeller Foundation but could organize to fulfil together a number of financial functions. The first goal of the small group formed by the Near East colleges was to coordinate the distribution of money and to avoid further internal conflicts. The immediate goal of this informal group was to distribute funds derived from the Charles M. Hall Estate, ${ }^{35}$ a massive donation to the ABCFM made upon his death by the aluminium magnate.

\subsection{Uneven Political Bases for Cooperation}

The Rockefeller Foundation was guided in its relations with the Near East Colleges Association by consideration of the local political situation first and foremost. The Foundation had been loath to invest in the Middle East as long as

32 Umar Ryad, "Muslim Response to Missionary Activities in Egypt: With a Special Reference to the Al-Azhar High Corps of Ulamâ (1925-1935)," in New Faith in Ancient Lands: Western Missions in the Middle East in the Nineteenth and Early Twentieth Century, Studies in Christian Mission 32, ed. Heleen Murre-van den Berg (Leiden: Brill, 2006), 281-307.

33 AUB/ASC, A.A.7.6.2, AUBites, 9, "STAU B, A.W.," Box 2, Nickoley to Staub (December 16, 1922).

34 Frank A. Ross, Charles L. Fry, and Elbridge Silbey, The Near East and American Philanthropy: A Survey, Conducted Under the Guidance of the General Committee of the Near East Survey (New York: Columbia University Press, 1929), 284.

35 RAC, RF, RF Diaries, Richard Pearce diaries (July 16, 1924); AUB/ASC, A.A.7.6.2, AUBites, 9, "Staub A.W.," Box 2, Staub to Dodge (October 16, 1924): Annex, "Five year financial program for Near East Colleges." 
uncertain political conditions prevailed. ${ }^{36}$ The intensified efforts of the trustees of the AUB in 1922-1923 and the repeated postponements by the foundation highlight the discrepancy between the reasons for the colleges to apply for RF aid and the foundation's criteria in granting it. The Rockefeller Foundation waited for the lull in military cooperation created by the Lausanne Treaty in July $1923,{ }^{37}$ before jumping on the occasion to start cooperation with the Near East colleges. It was making good of a narrow window of opportunity, following the military stabilization in Syria after the Lausanne treaty and before the Great Syrian revolt of the summer 1925. It sought to build on the goodwill manifested towards the AUB by the French High Commissioners, the heads of the French Mandatory administration, without antagonizing the Syrian population by working with the French colonizers. This was facilitated by the lack of interest of local French Catholic academic institutions for cooperation with American Protestant organizations.

The Rockefeller Foundation claimed to prioritize circumstances that allowed long-term plans, which required a favourable political environment. But here is the catch: RF and AU B officials did not see anything stable in that short period of relative calm, or in French rule for that matter. Rather, they were positioning themselves in view of the next, predictable round of confrontation, accepting the Mandatory regime while anticipating hostile trends in Syrian and Lebanese public opinion. In keeping with RF policy established in Europe, no cooperation was possible without cordial relations with the political authorities-indeed, without their participation. In Turkey, any cooperation that would seem to bypass the political authorities would have been viewed with suspicion by the Kemalist regime. ${ }^{38}$ The French Mandate, a Colonial republic under French tutelage but designed to have institutions of selfgovernment, was a different matter. As a state-in-the-making, it was of a hybrid, non-lasting nature. No pretence to favour long-term foreseeability would hold against that assessment, which makes it look as though the foundation entered full-scale cooperation headlong as soon as it could make sure it would not be seen as an intrusion by the powers-that-be.

A changing situation required caution vis-à-vis all actors concerned, not only the French, but Syro-Lebanese public opinion as well. Solidarity of American interests could only exist once that condition was fulfilled. The Rockefeller Foundation's approach was not to support American institutions in the Middle

\footnotetext{
36 AUB/ASC, A.A.7.6.2, AUBites, 9, "STAUB, A.W.," Box 2: Staub to Dodge (February 17, 1923).

37 Michael Provence, The Last Ottoman Generation and the Making of the Modern Middle East (Cambridge: Cambridge University Press, 2017), 155.

38 AUB/ASC, A.A.7.6.2, AUBites, 9, “StAUB, A.W.," Box 2: Moore to Dodge (April 6, 1924).
} 
East as a whole; ${ }^{39}$ but where it could support Americans, it would. The hybrid nature of the mandate provided a pretext to choose cooperation with the AUB: the criteria for cooperation devised by the foundation, namely, cooperation with local authorities, could be argued not to apply to the by definition external authority of the French Mandatory power. ${ }^{40}$

The assessment stressed the necessity to "go native" on every level. Pearce and Vincent completed it on their return to the United States with a report to the foundation on medical education in Syria. The French Jesuit Université Saint-Joseph, putting denominational belonging first and making do with catering for the needs of the Mandatory institutions anyway, would not cooperate. The Arab University of Damascus could not, for lack of equipment, staff, and academic standards. The AUB was blessed with a favourable image in the Middle East and a large hinterland of British colonies in the Middle East in need of English-speaking university-trained staff. ${ }^{41}$ Pearce and Vincent concluded by assessing that of the three institutions, the AU B had the best chances of middle-to-long-term survival. The conditions were ripe to strengthen the regional intra-American cooperation already functioning through the NER. Since the image of religious interference associated with missionary work had been dispelled, what was now required was to convince Syrians to make the AUB an institution of their own. This was one of the functions of the fundraising drive that followed the officialization of RF-Near East college cooperation.

\subsection{Changing Institutional Identities: Research Goals and Secular Outlook}

Another function of the Near East Colleges Association developed after 1927 with the expansion plan, namely, to provide coordination between the colleges in their relations with the Rockefeller Foundation. This facilitated the foundation's plan to transform the Near East colleges and the AUB in particular into research institutions aimed at preparing economic and social development. One condition for this was for the colleges to reach a critical mass enabling them to select researchers who would, in their time, be sent on fellowships to the United States and come back as trained researchers. ${ }^{42}$ This meant the colleges should not discourage potential Muslim students by displaying an openly Christian identity, as was still the case of Robert College and the ACG. ${ }^{43}$ Joint

Ross, The Near East in American Philanthropy, 285.

41 RAC, RF, FA 308, Box 551, File 3692: Richard M. Pearce, "Medical Education in Syria” (1924).

42 Schayegh, "The Interwar Germination," 654.

43 Ross, The Near East in American Philanthropy, 164. 
pressure to secularize would continue to be exerted by the trustees of the colleges, wary of missionaries; by the NER and later the Near East Foundation (NEF), with an experience in working with all denominations in spite of its clear Christian identity back home in America; and by the Rockefeller Foundation.

\section{Donors and Dependency}

Where did the Near East colleges get their funds from? Like a number of Protestant colleges in China, they were foundations established under the aegis of the ABCFM, which had historically provided the money for their creation, and worked with a network of patrician families that had made their ways into the boards of trustees of each and every college. Yet by the 1920s, the patterns and channels changed, with the arrival of philanthropies as a new type of major donor. Did the advent of the philanthropies' million-dollar grants change the approach of the colleges to funding? Especially, did it make them more responsive to pressure from donors? Did it differentiate them further from missionary institutions?

The end of the war and early post-war years were years of structural indebtedness for the Near East colleges. The economic situation made it impossible for them to maintain the principle of self-supportiveness that had been the norm. ${ }^{44}$

More preoccupying was the inadequacy between expenditure and supposedly corresponding sources of income. Boarding fees did not cover fully the overall boarding costs $(89 \%)$. Tuition fees covered less than half the expenditure for instruction $(48 \%)$. This went against a guiding principle of missions abroad, namely, that they should aim at being self-supportive and should at least cover their ordinary expenditure. With what money did the colleges survive, then?

\section{1}

The Traditional Way to Growth: Large Individual Donors

One of the central aspects of the work of the NER and of the RF involvement in the Middle East, beyond relief, was reconstruction. The word referred less to the localized effects of military destruction during World War I than to a massive effort of social engineering, among whose main tools was higher education. Pearce commented in 1925: "Syria is not Europe, the institution [the AUB] is fin-

$44 \mathrm{CUL} / \mathrm{RBML}, \mathrm{RC}, \mathrm{ACG}, \mathrm{Box} 3$, file 11: "Stated meeting of the trustees of the American College for Girls at Constantinople in Turkey, Held in New York City, Thursday, April 25, 1918." 
anced from America and the problem is not "emergency" in the sense of Central Europe, and I think the best term for the program is 'Wet nursing' ". 45 In the eyes of the foundation, external funding was sufficient to ensure the survival of the institution, but it was not enough to cover development, which also required specialized training.

$\mathrm{RF}$ practices of allying intensive funding and capacity building casts the foundation in opposition to earlier funding practices, especially nineteenthcentury ones. American gifts to the colleges meant first and foremost large individual gifts. These had long made the bulk of foreign missions' resources for investment, but the role of major donors had decreased through the 19th century: Sarah Flew shows with the case of major British foreign missionary societies such as the CMS that in the event of the loss of large individual donors, the society's operational capacity was no longer threatened. ${ }^{46}$ Missionary societies could rely on other sources of extraordinary income and remain afloat.

Gifts from large donors came with strings attached. Ideologically, donors expected missionary societies and protector states to stand for values compatible with theirs. Practically, most missionary societies preferred to reward major individual gifts with the naming of a piece of equipment, a room, or a building after the donor, rather than letting them retain bargaining power. Symbolic rewards were a way to minimize individualized donor dependency.

Under circumstances of financial emergency, missionary institutions saw no other option than to mobilize a network of well-to-do donors and accept their conditions. In 1922, the AUB negotiated a gift of $\$ 1$,ooo with a New Yorkbased immigrant originating from Damascus, N. Mallouk. The money was one example in a number of gifts destined to be used solely to fund scholarships for poor students - in particular Russian and Armenian refugees. ${ }^{47}$ In the Mallouk case, the condition was that it should help four students from Damascusthree Greek Orthodox and one Muslim — be selected for their academic proficiency and get an AUB education. ${ }^{48}$ Post-war emergency was liable to reinstate dependency on large individual donors, which the Near East colleges sought to avoid.

45 RAC, RF, Record Group 1.1 (hereafter: RG 1.1), box 2, file 11: Pearce to Carter (January 25, 1925).

46 Sarah Flew, Philanthropy and the Funding of the Church of England, 1850-1914 (London: Routledge, 2015), 138-139.

47 AUB/ASC, A.A.7.6.2, AUBites, 9, "StAUB, A.W." Box 2: Staub to Nickoley, (October 14, 1922).

48 AUB/ASC, A.A.7.6.2, AUBites, 9, "StAuB, A.W.", Box 2: copy of Walter Booth Adams to N.S. Mallouk (April 28, 1922). 


\subsection{Missions in the 19th Century and the Democratization of Funding}

Of course, missionary societies did not oppose large donors and small donors. The latter helped secure the operating costs of the missionary organizations, and establish them as major, reliable institutions. The reverse was true: large individual donors could be useful as models, in order to create larger pools of small donors, on a professional or communitarian basis for instance.

The mobilization of alumni soon highlighted the resources of the Middle Eastern diasporas. Branches of the alumni association were soon founded, not only across the Levant, but in North and South America as well. Prominent and affluent alumni would be useful in starting donation drives among the diasporas. ${ }^{49}$ Promises of grants, individual and institution, were supposed to have cumulative effects. ${ }^{50}$ The multiplication of branches of the alumni association abroad testified to the intrication of long-distance nationalism and professional links maintained through the alma mater.

The donation drive benefited from the conjuncture, as long-distance nationalism was aroused in the Syrian diasporas by the events in the French Mandate. Syrian public opinion abroad was turning against the French Mandatory power, especially after the beginning of the Great Syrian Revolt in the summer of 1925 . After the denunciation in the American press of the bombing of Damascus by the French in October 1925, ${ }^{51}$ the AUB and the United States were seen as political allies against French colonial exactions.

\subsection{State Subsidies and Influence}

"There is no such thing as a free lunch", as Milton Friedman put it, or gratuitous state subsidies for that matter; but they do not entail automatically donor-dependency on the state. Not only is the effectiveness of donor dependency indexed on the state's capacity of control over aid receivers, but state administrations are interventionist to varying degrees. In the Late Ottoman and Interwar period, France stood out as an example of diplomatic interventionism over missionary institutions placed under its protection, and the United States much less so. French governmental subsidies, given on a yearly basis on ministerial budget or out of the profits of the Pari Mutuel horse races, were carefully weighed at the Quai d'Orsay, strenuously negotiated, and often hotly

49 AUB/ASC, A.A.7.6.2, AUBites, 9, "STAUB, A.W.," Box 2: copy of Walter Booth Adams to N.S. Mallouk (April 28, 1922).

50 AUB/AsC, A.A.7.6.2, AUBites, 9, "Staub, A.w.," Box 2: Staub to Nickoley, (December 6, 1922).

$5^{1} \quad$ Susan Pedersen, The Guardians: The League of Nations and the Crisis of Empire (Oxford: Oxford University Press, 2015), 142-168. 
contested afterwards among disgruntled candidates. And yet even French diplomatic control over aid receivers had its limits. Individuals were able to carve their autonomy against consular and ambassadorial power, due to their connections within the church and the latter's complex balance of power. With the end of French monopoly on the protection of Latin Catholic missions in 1898 , Germany, Austria-Hungary, and Italy in particular started vying for the protection of "national" institutions through injecting subsidies, which in return meant closer oversight of their operations. ${ }^{52}$ Still, the relation worked both ways, and due to the international character of the Catholic religious staff, no situation of protection implied perpetual loyal or vertical power relations.

Us administrations seemed to keep a more hands-off policy towards missionary institutions than other Western powers. Personalities associated with missionary organizations were in close, frequent contacts with government officials, and humanitarian crises were a case when the us administration would summon missionary societies and their men on the ground to initiate relief operations. The establishment of the American Committee for Armenian and Syrian Relief was an instance of the relation working at the initiative of the government: together with fellow millionaire Charles Crane, patrician Cleveland Dodge, a close friend of us president Woodrow Wilson and the father of future AUв president Bayard Dodge, was called in 1915 by Us Ambassador to Constantinople Henry Morgenthau to form the American Committee for Armenian and Syrian Relief. ${ }^{53}$ Yet the correspondence between the trustees and the colleges shows them less often receiving orientations from the State Department than trying to assume an influence on us diplomacy. The letters exchanged between Albert Staub, the secretary of AUB's board of trustees, and the presidency of the AUB shows the former reacting upon political events with foreign policy implications: Staub cheers for the results of the midterms of 1922, seeing them as a payback for the Republicans' refusal to ratify the peace treaties and get a proactive role in the Middle East through the Armenia mandate. ${ }^{54}$ He is summoned to the us State Department following the signature of the Turco-American "Treaty of Amity and Commerce" signed in Lausanne in 1923

52 French Foreign Ministry Archives, Nantes, AP, Consulat de Beyrouth, Série A, 314, French Ambassador to the Holy See to Delcassé, Rome (May 8, 1902); Consulat de Beyrouth, Série A, 350, report: "Aperçu sur les œuvres diverses établies en Palestine et du moyen d' assurer et de développer l'influence française” [ca. 1903?].

53 Joseph L. Grabill, "Cleveland H. Dodge, Woodrow Wilson, and the Near East," Journal of Presbyterian History 48, no. 4 (Winter 1970): 255.

54 AUB/ASC, A.A.7.6.2, AUBites, 9, “STAUB, A.W.," Box 2: Staub to Nickoley (November 9, 1922). 
alongside the peace treaty between Turkey and Greece, but for advice. ${ }^{55} \operatorname{In} 1926$, he makes vain efforts to influence the Senate in favour of ratifying the treaty, ${ }^{56}$ which he sees as the condition for American institutions to go on working in Turkey, in the shadow of businessmen desirous to do business in Turkey. ${ }^{57}$ In line with these efforts at influencing policy, Staub devoted much time, alongside the organization of the donation drive of $1925^{-1926}$, to fleshing out the Newsletter of the Near East Colleges Association. The goal of the publication was first and foremost to give the colleges publicity and facilitate the collection of funds. But after the success of the donation drive for the contingency plan, Staub came to see the newsletter as a potential tool of influence. Rather than being funded and remote-controlled by the state, the Near East colleges sought deliberately to assume a role mixing lobbying and expertise vis-à-vis us diplomacy. Their capacity to collect donations boosted their political influence.

\section{4 "We Mean to Get the Million All Right": A Crowdfunding-Philanthropy Mix}

Why did the Near East colleges, with their traditional channels of funding and no dependency on the Us Treasury, apply in the early 1920s for RF money when it came with stringent procedures of control? As said before, the colleges were pressed for money. Moreover, cooperating with the Rockefeller Foundation was not exclusive of seeking other, more traditional sources of cash, in order to constitute a sufficient endowment and shore up its expanded budget. In this, the Near East colleges knowingly followed the model of their Chinese counterparts; yet the commitment of the foundation in the reorganization of medicine in China was also distracting it away from any serious investment in the Middle East.

Near East colleges officials understood RF grants to mean a jump in the financial resources at their disposal. The main aid receiver in the Middle East during the Interwar period, the AUB, ended up ranking in the middle among $\mathrm{RF}$ grantees of the period. ${ }^{58}$

$\mathrm{RF}$ money was a guarantee for other potential benefactors as well. The argument was used on N. Mallouk to encourage him into going through with his offer for scholarships: "[you] have probably seen what the Rockefeller Fund has

55 AUB/ASC, A.A.7.6.2, AUBites, 9, "STAUB, A.W.," Box 2: Staub to Dodge (April 12, 1924).

56 George Harris and Nur Bilge Criss, Studies in Atatürk's Turkey: The American Dimension (Leiden: Brill, 2009), 11.

57 AUB/ASC, A.A.7.6.2, AUBites, 9, "StaUb, A.w.," Box 3: Staub to Dodge, (September 23, 1926); Ibidem (January 25, 1927).

$5^{8}$ Schayegh, "The Interwar Germination," 66o. 
promised us and other interests are backing us. We mean to get the Million all right". ${ }^{9}$ What was the goal of the colleges, chasing two rabbits at a time, and were Rockefeller officials at home with that?

The Rockefeller Foundation was concerned with the capacity of the Near East colleges to find alternative sources of funding. The issue was double-edged. Banking on the fund-raising capacity of the Near East colleges to supplement $\mathrm{RF}$ funds ensured that the foundation did not have to bear the whole financial weight of the overhaul of the colleges. But multiple sources of fundings could make the colleges less responsive to RF control and pressure. At the beginning of the donation drive, Pearce expressed the latter view. He dismissed crowdfunding as the characteristic missionary way of fund-raising, and one that had proved problematic for the foundation elsewhere:

Your letter and their memoranda seem to show that they are after all they can get. I have always said that the American University of Beirout [sic] was not to be regarded as a Missionary Institution, but the present demands indicate that I was wrong: they seem to be after all they can get. ${ }^{60}$

The Near East Colleges Association's crowdfunding capacity was beneficial for their cooperation with the foundation. The reason Pearce was irked by the funding practices of the AUB was not its trying to preserve its autonomy through alternating among its benefactors, but the university's apparent treatment of the foundation as a cash machine and a publicity argument visà-vis other donors. It was RF policy to finance institutions so as to enable them to become self-supportive on a larger scale after RF-funded projects had ended.

But did RF grants facilitate or complicate the financial autonomy of the colleges? There was a case to be made for encouraging aid-receiving institutions to supplement $\mathrm{RF}$ fundings with donation drives, as this would, in time, minimize the effects of the transition out of aid and give institutions a basis of financial stability. The whole point of the $1925^{-1926}$ plan $^{61}$ and of the ensuing expansion plan ${ }^{62}$ was to clear the debts of the colleges first, and to constitute and consolidate an endowment to finance their expanded budget. There was a division

59 AUB/ASC, A.A.7.6.2, AUBites, 9, "Staub, A.W.," Box 2: copy of Walter Booth Adams to N.S. Mallouk (April 28, 1922).

6o RAC, RF, RG 1.1, Box 2/11: Richard M. Pearce to Walter S. Carter (January 25, 1925).

61 RAC, RF, RF Diaries, Richard Pearce diaries (April 6, 1924).

62 RAC, RF, RF Diaries, Richard Pearce diaries (June 3, 1927). 
of work. RF money would be concentrated on endowing the new equipments the foundation pressed for, and on developing medical and later social science teaching and research. ${ }^{63}$ The colleges committed themselves to finding the bulk of the money necessary to reconstitute and expand their endowment in order to receive $\mathrm{RF}$ funds. ${ }^{64} \mathrm{RF}$ funds and other sources of funding were not alternatives: they conditioned one on another.

The foundation exerted pressure on the process of donation collection, but not on the methods, which ended up being what Pearce had called "missionary" - based on partly missionary networks and, above all, on crowdfunding. The scale of RF funding was a pull factor for donors and an incentive for the trustees of the colleges to step up the campaign directed at potential donors. Alongside the newsletter of the Near East colleges, publicity, and conferences, an Oriental bazaar was organized to kickstart the donation drive at the end of 1924, with the sale of products from Armenian refugee and Syrian charities and the participation of notable figures in the missionary world, as well as George Vincent. ${ }^{65}$

The colleges maintained their traditional missionary ways of collecting funds, but even on these the foundation exerted oversight. The relation was more of control than of dependency: the complementarity between the modes of funding was aimed, not just at anticipating the transition out of RF projects, but already at preventing RF money from becoming part of the ordinary budget of the colleges. The foundation considered that they should become self-supporting again as soon as possible. Was pressure on funding used as efficiently on the expenditure of the colleges? Were the colleges as subservient to the specific agendas of the foundation as they were to the financial conditions it laid down?

The notion of agenda-dependency can be used to describe the creation of aid-induced obligation to enforce the agendas of the donor, but this can refer to two forms of obligation: effective compliance (performance obligation) or demonstration of steps taken towards compliance (best-efforts obligation). Failure to comply does not necessarily entail the end of cooperation, which

63 RAC, RF, RF Diaries, Richard Pearce diaries (May 22, 1924).

64 AUB/ASC, A.A.7.6.2, AUBites, 9, "STAUB, A.W.," Box 2: Staub to Dodge (May 23, 1924).

65 AUB/ASC, A.A.7.6.2, AUBites, 9, "Staub, A.W.," Box 2: Moore to Crawford (December 26, 1924). 
would deprive donors of power over aid receivers. However, the stress of early 2oth-century economics on budget orthodoxy put pressure on economic actors, both public and private, to strive towards budget balance, and therefore to get out of debt as quickly as possible. This made donor-receiver relations more comminatory. The influence of the Rockefeller Foundation was mostly felt on the expenditure side, where it could impose its norms and its agendas. The insider knowledge held by Near East colleges officials often enabled them to anticipate its demands, but the foundation was in the habit of threatening to withhold or fail to renew its grants in order to bring aid receivers back in line. RF-funded projects were devised so as not to induce a structural need for aid in the budget of receiver institutions; the counterpart was that the pressure on enforcing the foundation's recommendations was direct. In the case of the Near East colleges, compliance to RF norms had its limits; but cooperation had a broader, more structural influence by bringing about a rationalization of expenditure.

The Rockefeller Foundation was more involved in the architecture of training and research than in individual cases, which led it to exert an influence on the disciplines and the contents taught in the Near East colleges. Whereas missionary schools and colleges sought to instill, if not an outright religious morality, at least one clearly influenced by Protestantism, ${ }^{66}$ the foundation was more interested in instilling in students deontology and professional procedures. $^{67}$

\section{Professionalizing the Staff: Focusing on Professional Procedures, a} Secularization of Recruitment?

Another focus of RF pressure was the standardization of professional procedures. Sending students and alumni on scholarship to the United States served the purpose, among other goals. So did the inspection tours that followed the establishment of cooperation between the foundation and the colleges. At the decisional level, it created stronger relations between the authorities of the colleges and globalized, though largely Western, scientific communities.

Did the Rockefeller Foundation's preference for work with secularized institutions translate into pressure regarding recruitment policy? The answer is not clear cut. First, cross-denominational recruitment did not make sense from the

66 Boulos, European Evangelicals in Egypt, 131-137.

67 Schayegh, "The Interwar Germination," 671. 
point of view of the foundation alone, but also for the colleges themselves. This was due to the ambiguities and evolutions of the notion of religious freedom as promoted by the us government and American private voluntary organizations alike. Religious freedom had become an argument for the us diplomacy to support missions in the late Ottoman Empire. ${ }^{68}$ It had meant a guarded support for missionary proselytizing as well as support for coexistence between Muslim and non-Muslim communities in the face of growing inter-communal violence. Yet by the time the Near East Colleges Association and the Rockefeller Foundation formalized their cooperation, circumstances had changed beyond recognition. First, religious freedom had been weaponized against missionary institutions, in the case of the 1909 student strike at the SPC: non-Christian students had invoked it in order to be exempt of the obligation of attending Bible classes and religious service. ${ }^{69}$ Then, with the mass violences of World War I and the post-war conflicts, the non-Muslim population of the new state of Turkey had all but disappeared and the Kemalist authorities used their own notion of laiklik (secularism) and the new demographic composition of the country against Christian missions. ${ }^{70}$ Invoking religious freedom could work to justify the uncomfortable but ongoing presence of missionary institutions on Turkish territory, but not the protection of proselytizing institutions; hence the urgent need of the American colleges in Istanbul to integrate Turkish staff in their midst. In Beirut, on the contrary, power had been seized by a state identified alternately as secular and Christian. Active Protestant proselytism would antagonize the majority of the population of the Mandate, but promoting religious coexistence and interactions in the name of religious freedom was an effective tool of cultural diplomacy in order to conquer local public opinion. ${ }^{71}$

Yet in practice, most of the Western candidates and recruitees of the Near East colleges had a missionary past or family. Not only were they referred to that pedigree in the international correspondence of the Near East Colleges Association and in letters to the Rockefeller Foundation; their missionary history was

68 Henry Otis Dwight, Treaty Rights of American Missionaries in Turkey (New York: Foreign Missions Library, 1893), 7 .

69 Jens Hanssen, Fin de Siècle Beirut: The Making of an Ottoman Provincial Capital (Oxford: Clarendon Press, 2005), 186.

70 Rufat N. Bali, The Saga of a Friendship:Asa Kent Jennings and the American Friends of Turkey (Istanbul: Libra, 2009), 335 .

71 Jennifer Dueck, "International Rivalry and Culture in Syria and Lebanon under the French Mandate," in Searching for a Cultural Diplomacy, eds. Jessica C.E. Gienow-Hecht and Mark

C. Donfried (New York: Berghahn, 2013), 137-161. 
seen as of value to work in the Middle East. ${ }^{72}$ This preference in the face of outward assertions of religious freedom and repudiation of missionary methods cannot be reduced to a hidden agenda of cultural influence and subterranean religious propaganda. Three other factors at least have to be taken into account. The first one lies in the professional qualities attributed to missionary, to wit, a "spirit" full of enthusiasm, associated with an experience of foreign fields. ${ }^{73} \mathrm{The}$ second factor is financial, as missionaries were assumed to be liable to accept the salaries paid by the Near East colleges, whose reduced amount in comparison with similar work in the United States explains much of the high turn-over among the Western staff. ${ }^{74}$ Lastly, hiring staffers of missionary background was also thought as a way to prevent what was the alternative way to prevent the turn-over of Western teachers in the medical sciences, namely, allowing them to keep a private practice by the side. The practice was common among missionary medical schools abroad, but it ran against the RF goal of developing institutions of research. At the Peking Union Medical College, the main focus of RF medical projects in China, Pearce had been able to observe the problem: "I feel that if the present policy is to continue there will be great danger of establishing a Mayo clinic with a medical school attached".75 At AUB, Rockefeller fellowships were one way to steer practitioners away from their private practices and back to research. ${ }^{76}$

The relationship that developed between the Rockefeller Foundation and the Near East Colleges Association during the Interwar period was clearly one of influence. The foundation exerted influence on both an individual and a strategic level, be it on priorities of academic development, politics, staff recruitment, or conceptions of social engineering. By and large, the administrations of the colleges welcomed RF involvement through higher standards and the goal of becoming research institutions. The result was not equally satisfactory for all colleges, though, as the AUB was given a prominent role above consid-

72 See for instance: RAC, RF, Pearce diaries (September 19, 1924); Mary Beard, (October 24, 1927); (December 2, 1927); AUB/ASC, A.A.7.6.2, AUBites, 9, "STAUB, A.W.," Box 3, Staub to Dodge (August 31, 1926).

73 RAC, RF, Pearce diaries (December 2, 1927).

74 AUB/ASC, A.A.7.6.2, AUBites, 9, "STAUb, A.W.," Box 2, Staub to Dodge (August 11, 1924).

75 RAC, RF, Pearce diaries (February 14, 1921).

76 AUB/ASC, A.A.7.6.2, AUBites, 9, “StaU B, A.W.," Box 2, Nickoley to Staub (May 21, 1923). 
erations for regional governments, whereas the colleges in Istanbul saw their academic perimeter curbed by RF consideration of the nationalist government of the Republic of Turkey: in 1925, the ACG had to close down its brand new medical school for women under RF pressure, and as a display of goodwill to the Kemalist authorities.

RF influence was obtained through an open carrot-and-stick approach, based on the promise of funding. The Near East colleges appear to have been more than willing to submit to RF procedures and injunctions, plagued as they initially were by ordinary expenditure debts and the cost of their relief activities. They were less reluctant than their counterparts in China to adhere to RF methods and forgo openly missionary identities. Philanthropy funding completed the evolution out of religious proselytism which had been accelerated by the colleges' wartime and post-war humanitarian repurposing.

In the process of negotiating cooperation and afterwards, the Near East colleges made use of their image as being less missionary and more secular than most other American Protestant institutions in the region. While the Rockefeller Foundation was not anti-missionary, it had become wary, through its work in China, of missionaries attempting to maintain the priority of their religious calling. I argue, however, that missionary meant different things in different contexts: the foundation saw the epithet in a positive light when it referred to the genealogy of American recruitees, their values and their field experience abroad, in humanitarian action especially; with discomfort as to actual proselytizing; and with ambivalence when it came to funding methods. The religious identification of the aid-receiving institutions mattered to the foundation as a donor, and the more proactive missionaries were spared dependency on it, at the price of protracted shortage of cash. Sticking to one's religious values did make a difference. Yet the relation of causality-that secularization would have helped make the Near East colleges dependent on RF money - fails to apply the other way around. The Near East colleges retained its Christian missionary inspiration on the inside, out of sight. Its proactive subservience to the recommendations of the foundation did not stem from a conversion to secular values, but from a sense of opportunity for higher education in the Middle East, and from insider knowledge about the demands of the foundation, thanks to relations with American Colleges in China.

For these reasons, the RF-NECA relationship can be characterized by agenda dependency, but cannot be assimilated to the kind of subservience to donors which contemporary NGOs are commonly denounced for. Agenda dependency, in this instance, followed and pushed further the dropping of the colleges' missionary agenda and the recasting of their religious identity into that of beacons of religious freedom. The success of the donation drives organized 
by the boards of trustees of the colleges do not indicate a loss of support or confidence in their operational norms or in their adherence to their original Protestant values. These drives did not curtail RF influence on the agenda of the colleges in the short run either, coordinated as they were with Rockefeller authorities. But they guaranteed the capacity of the colleges to grow out of dependency on RF funding in the long run. The situation at hand is different from present-day patterns of donor dependency, in which NG O s and other institutions come to need on a regular basis continued support from an institutional donor, to whom they become subservient; RF influence on the Near East colleges had a horizon: its emergency plans and grants for reconstruction were understood to be as temporary as possible. The goal, reflecting a lingering Victorian ideal of self-reliance, was to kick-start institutions meant to become self-supporting. There was an entry cost for the Near East colleges, who had to submit to RF procedures of evaluation. Yet as the case of the AUB and its rival institutions in Beirut and Damascus shows, the effort promised to pay off. The missionary practice of crowdfunding did not offset RF influence, it made the temporary character of RF aid a realistic perspective. Nowadays, aid attribution is competitive, which creates relations of clientele: aid receivers cultivate the good will of their donors. The procedural costs of submitting a grant application make it an investment, the viability of which depends on reconduction. The depth and nature of donor dependency change with the time frame of aid ${ }^{77}$ and the degree of competition for funding. With little competition surrounding the Near East colleges, it did little matter to their American benefactors how strongly Protestant and missionary those institutions came out.

And now, to get back to the issue of the role of missions in American strategies. The archives show the trustees of the Near East Colleges Association actively attempting to influence American foreign policy, rather than being given directions from Washington. Presuming one strategy guiding the Rockefeller Foundation and the colleges runs against the fact that there were roads not taken and cul-de-sacs such as the medical school of the ACG, reciprocal interrogations on the intents of the various actors involved, and ambiguities on the goals to be attained. While the Rockefeller Foundation was set on rural development and this goal was by and large accepted by the AUB, national governments in the Middle East nurtured other plans for the graduates they recruited. The foundation, determined to cooperate directly with the Turkish government, probably came upon difficulties in trying to impose such an 
agenda on the colleges in Istanbul, as the Kemalist régime wanted to industrialize the country and bring Western firms and experts to that end. Moreover, the convergence of operations between American private voluntary organizations in the Middle East and philanthropies was not an abstract view. It was experienced in the field, in the emergency and relief work. The relations between the Rockefeller Foundation, the Near East College Association and the NER were sites of production of techniques of cooperation that would later be institutionalized within the us State Department and, much later still, be identified as a specific form of power within international relations: soft power. Even regarding a major American ideological export product, religious freedom, the agency of the colleges should be separated from the strategies of the Rockefeller Foundation, let alone of the American government. Vis-à-vis this agenda, American diplomacy was an enabler, creating the position of diplomatic privilege under which the Near East colleges could work. The content of the agenda was left in the hands of other actors, rather than being channelled through them as part of a larger strategy and a common national agenda. ${ }^{78}$ The Rockefeller Foundation promoted religious freedom from a perspective of efficiency in predominantly non-Christian settings in China and the Middle East, together with a growing distrust, gained in China, with the spirit of denominational exclusivity displayed by certain missionaries. The Near East colleges themselves were wary of hurting local public opinion, and against a backdrop of more proactive missions working in the region, gave religious freedom the meaning of non-interventionism on the part of Protestant institutions, religious coexistence in their midst, as well as deontology and character training under clear but unspoken influence of Protestant ethics for their students. This way, they could claim to their financial backers to remain true to their Christian values while creating a pattern of interdenominational cooperation that would also become part of us modernization policies.

78 On the distinction between the "subjective", strategic exertion of power and the "objective" power given by a position of privilege, and the idea that the assumed non-intrusive character of "soft power" as conceptualized by Joseph Nye is often undermined by active exertion of power, see Edward Lock, "Soft Power and Strategy: Developing a 'Strategic' Conception of Power," in Soft Power and us Foreign Policy: Theoretical, Historical, and Contemporary Perspectives, ed. I. Parmar and M. Cox (London: Routledge, 2009), 32-50. 


\section{Bibliography}

\section{Primary Sources}

American University of Beirut. Archives and Special Collections (AUB/ASC).

Boğaziçi Üniversitesi Archives, Istanbul (CUL/RBML, RC).

American College for Girls Records (ACG). Box 20, file 18: President's Report with Statistics 1920-1921.

Rockefeller Archives Center (RAC). Tarrytown, New York.

Rockefeller Foundation Record (RF).

\section{Secondary Sources}

Abu-Sada, Caroline. oNG Palestiniennes et construction étatique: L'expérience de Palestinian Agricultural Relief Committees (PARC) dans les Territoires occupés palestiniens 1983-2005. Beyrouth: Presses de l' IFPO, 2013.

Baick, John S. "Cracks in the Foundation: Frederick T. Gates, the Rockefeller Foundation, and the China Medical Board." The Journal of the Gilded Age and Progressive Era 3, no. 1 (2004): 59-89.

Bali, Rufat N. The Saga of a Friendship: Asa Kent Jennings and the American Friends of Turkey. Istanbul: Libra, 2009.

Beaumont, Peter. "Israel Passes Law to Force NGo s to Reveal Foreign Funding." The Guardian, July 12, 2016. Accessed on April 27, 2018. https://www.theguardian.com/ world/2016/jul/12/israel-passes-law-to-force-ngos-to-reveal-foreign-funding.

Boulos, Samir. European Evangelicals in Egypt (1900-1956): Cultural Entanglements and Missionary Spaces. Studies in Christian Mission 48. Leiden: Brill, 2016.

Cook, Albert. "Medical Itineration." Mercy and Truth vol. 5, no. 66 (June 1902): 174179 .

Crabtree, Loren W. "Andrew P. Happer and Presbyterian Missions in China, 1844-1891." Journal of Presbyterian History 62, no. 1 (Spring 1984): 19-34.

Dueck, Jennifer. "International Rivalry and Culture in Syria and Lebanon under the French Mandate." In Searching for a Cultural Diplomacy, edited by Jessica C.E. Gienow-Hecht and Mark C. Donfried, 137-161. New York: Berghahn, 2013.

Dunch, Ryan. "Science, Religion, and the Classics in Christian Higher Education to 1920." In China's Christian Colleges, edited by Daniel Bays and Ellen Widmer, 57-8o. Stanford: Stanford University Press, 2009.

Dwight, Henry Otis. Treaty Rights of American Missionaries in Turkey. New York: Foreign Missions Library, 1893.

Ekbladh, David. The Great American Mission: Modernization and the Construction of an American World Order. Princeton: Princeton University Press, 2010.

Flew, Sarah. Philanthropy and the Funding of the Church of England, 1850-1914. London: Routledge, 2015 . 
Gardey, Delphine. Ecrire, Calculer, classer: Comment une révolution de papier a transformé les sociétés contemporaines, 1800-1940. Paris: La Découverte, 2008.

Grabill, Joseph L. "Cleveland H. Dodge, Woodrow Wilson, and the Near East." Journal of Presbyterian History 48, no. 4 (Winter 1970): 249-264.

Gür, Asl. "Robert College: Laboratory for Religion, Shrine for Science-Transculturation of Evangelical College Model in Constantinople." In American-Turkish Encounters: Politics and Culture (1830-1989), edited by Nur Bilge Criss, Selçuk Esenbel, Tony Greenwood, and Louis Mazzari, 48-6o. Newcastle upon Tyne: Cambridge Scholars Publishing, 2011.

Hanssen, Jens. Fin de Siècle Beirut: The Making of an Ottoman Provincial Capital. Oxford: Clarendon Press, 2005.

Harris, George, and Nur Bilge Criss. Studies in Atatürk's Turkey: The American Dimension. Leiden: Brill, 2009.

Harris, Paul W. "Cultural Imperialism and American Protestant Missionaries: Collaboration and Dependency in Mid-Nineteenth-Century China." Pacific Historical Review 6o, no. 3 (August 1991): 309-338.

Hauser, Julia. German Religious Women in Late Ottoman Beirut: Competing Missions. Coll. "Studies in Christian Missions." Leiden: Brill, 2015.

Human Rights Watch. "Egypt: New Law Will Crush Civil Society," June 2, 2017. Accessed April 27, 2018. https://www.hrw.org/news/2017/o6/o2/egypt-new-law-will-crush-civ il-society.

Kennedy, Charles H., Ijaz Hussein, and S. Akbar Zaidi. "Reconsidering the Relationship between the State, Donors, and NGos in Bangladesh [with Comments]." The Pakistan Development Review 38, no. 4 (Winter 1999): 489-510.

Lankester, A. "Some Observations on General Mission Policy." Mercy and Truth vol. 1, no. 10 (October 1897): 219-223.

Lankester, H. "Medical Missions in Theory." Mercy and Truth vol. 3, no. 38 (February 1900): 37-42.

Lautz, Terril E. "The svm and Transformation of the Protestant Mission to China." In China's Christian Colleges: Cross-Cultural Connections, 1900-1950, edited by Daniel Bays and Ellen Widmer, 3-19. Stanford: Stanford University Press, 2009.

Lefebvre, Jeffrey A. "Donor Dependency and American Arms Transfers to the Horn of Africa: the F-5 Legacy." The Journal of Modern African Studies 25, no. 3 (September $1987): 465-488$.

Little, John Branden. "Band of Crusaders: American Humanitarians, the Great War, and the Remaking of the World." PhD diss. in history, University of California (Berkeley), 2009 .

Lock, Edward. "Soft Power and Strategy: Developing a 'Strategic' Conception of Power." In Soft Power and Us Foreign Policy: Theoretical, Historical, and Contemporary Perspectives, edited by I. Parmar and M. Cox, 32-50. London: Routledge, 2009. 
Maksudyan, Nazan. Orphans and Destitute Children in the Late Ottoman Empire. Syracuse, NY: Syracuse University Press, 2014.

Mills Patrick, Mary. A Bosphorus Adventure: Istanbul (Constantinople) Woman's College, 1871-1924. Stanford: Stanford University Press, 1934.

Near East Relief. Report to Congress for 1925. New York: Near East Relief-National Headquarters, 1926.

Petersen, Marie-Juul. For Humanity or for the Umma? Aid and Islam in Transnational Muslim NGOs. Oxford: Oxford University Press, 2016.

Pedersen, Susan. The Guardians: The League of Nations and the Crisis of Empire. Oxford: Oxford University Press, 2015.

Provence, Michael. The Last Ottoman Generation and the Making of the Modern Middle East. Cambridge: Cambridge University Press, 2017.

Ross, Frank A., Charles L. Fry, and Elbridge Silbey. The Near East and American Philanthropy: A Survey, Conducted Under the Guidance of the General Committee of the Near East Survey. New York: Columbia University Press, 1929.

Ryad, Umar. "Muslim Response to Missionary Activities in Egypt: With a Special Reference to the Al-Azhar High Corps of Ulamâ (1925-1935)." In New Faith in Ancient Lands: Western Missions in the Middle East in the Nineteenth and Early Twentieth Century. Studies in Christian Mission 32, edited by Heleen Murre-van den Berg. Leiden: Brill, 2006.

Schayegh, Cyrus. "The Interwar Germination of Development and Modernization Theory and Practice: Politics, Institution Building, and Knowledge Production Between the Rockefeller Foundation and the American University of Beirut." Geschichte und Gesellschaft 41, no. 4 (October-December, 2015): 649-684.

Sharkey, Heather J. "Introduction: The Unexpected Consequences of Christian Missionary Encounters." In Cultural Conversions: Unexpected Consequences of Christian Missionary Encounters in the Middle East, Africa, and South Asia, edited by Heather J. Sharkey, 1-26. Syracuse, NY: Syracuse University Press, 2013.

Ventura, Lorella. Hegel in the Arab World: Modernity, Colonialism, and Freedom. London: Palgrave MacMillan, 2018.

Vincent, George E. The Rockefeller Foundation. A Review for 1919. Public Health and Medical Education in Many Lands. New York: The Rockefeller Foundation, 1920.

Wang, Dong. Managing God's Higher Learning: U.S.-China Cultural Encounters and Canton Christian College (Lingnan University) 1888-1952. Lanham, MD: Lexington Books, 2007.

Watenpaugh, Keith David. Bread from Stones: The Middle East and the Making of Modern Humanitarianism. Berkeley: University of California Press, 2015. 